\title{
Re: Re/mixing the Remix
}

\author{
Randall Everett Allsup \\ Teachers College Columbia University, New York, USA
}

The aim of this brief essay is to thank contributing writers for their varied and critical reviews of my book Remixing the Classroom: Toward an Open Philosophy of Music Education. I consider the collection as a kind of assemblage-fractured, colliding, and reattaching texts that shift shape as readers enter and exit as they please. I brush lightly on themes that are important to me: the invitation to read within and outside frames; the notion of openness as something felt and longed for; a continued critique of Authorship, Mastery, and the Law; and a vision of arts education in which searching is prolonged and the impulse to clarify is (for the sake of truth) purposefully attenuated.

Keywords: music, education, philosophy, openings

here is no greater honor for a writer than to be closely read. The contributors to this special issue, to whom I offer my heartfelt thanks, provide a powerful illustration of how to engage with a text. Some wonder; others argue, defend, or extend. Some explain. But all read from their particular vantage point. Their achievement is profound and everyday: they changed a thing they came in contact with, in this case the book that I wrote over a span of three years, Remixing the Classroom: Toward an Open Philosophy of Music Education. ${ }^{1}$ I certainly didn't “Author" this manuscript, and I don't think I "created” it either. Better said: it was assembled ... from memory, experience, reading, and interaction. In turn, the contributors to this issue are remixing the remix. Like rabbits in a burrow, their thinking extends the book in multiple directions, expanding from a temporary starting point until you (the next reader) are left to find your way through a warren of new openings, secret passages, new delights and dead endsbut mostly, new paths in and new paths out. There's a saying in China, the clever rabbit knows two ways out. I hope you (the next reader, the now reader, a clever rabbit) join us in multiplying. 
I inherit the belief that reading is a form of quest. I read, or listen, to know and to understand, but also to lose my way, to trespass what I know to be true or what I have been told is true. The original title of this book was A Longing for Openings. Openness, of course, is an abstraction-something felt, but out of reach. Like the concept of democracy, it must be made and remade, and our efforts are always provisional. Once a discovery is made, once a truth is found, we may become aware of new fences, and a new decision must be summoned to keep on looking and hearing. From an educator's standpoint it is important to consider that the search for truth is not the same thing as an effort at clear thinking. Yes, clarity and truth may intersect momentarily (and it is wonderful when they do), but they are different manifestations of searching. I might argue that clarity of vision is a perilous aim for an educator, as one might be tempted to awaken others on their own behalf-to teach my truth to you, or to assume a course of travel by me, for you. The Master is always convinced he knows better than you.

I hope that readers of this special issue recognize in A Longing for Openings (now known as the easier-to-sell title Remixing the Classroom-thanks editors...I think...) that there is no longer and never was an original Work from which an explication of the Author's intentions could be provided. The text is inherently unstable because it requires your attachments and your collisions. These multiply, and with hope, they ignite richer (and stranger) questions-questions the writer may or may not have intended. Edward Said famously probed the outer borders of canonic writers like Charles Dickens and Jane Austen to read beyond the intended frame-to see with the eyes of an outsider what was there/not-there (empire, colonialism, orientalism). ${ }^{2}$ My point is not to compare myself to Said, but to insist that you do to me what Said did to Dickens and Austen. Moreover, Said didn't call his method (his pursuit of truth) dialectical analysis or binary thinking, but counterpoint, an act of naming, an act of critical reading, in which you consider what you are told is true (by the Author, by the Master, by standards of practice, etc.) against/ alongside how you see, know, and feel differently. The Master is always surprised when he is told that he can't see everything.

One way to look beyond frames and fences is to destabilize a Work, which is a conceptual act of productive study, moving beyond explication or computation to existence within a methodological field of exploration. ${ }^{3}$ The text in other words "is experienced only in an activity of production." 4 It is the difference between learning about (where you are outside, looking at, obeying, being taught) and being among (where you are attached, within, and in counterpoint: "its constitu- 
tive movement is that of cutting across. In particular, [the text] can cut across the work, several works.").5 I almost never teach a singular piece of music (or study a singular manuscript) without placing it in close proximity to another. With regard to the Law, I enjoy the collisions and collusions that result. Now, this process is not any kind of a great mystery, or even very difficult to do. To create a field of study, a teacher looks at the classroom as some kind of ineffable agreement-as a random group (usually) that has chosen to spend a small amount of time together, composed of different persons (we can be texts, too) from multiple backgrounds and outlooks, never to be repeated. Our goal is to make something new. We become readers and writers, a different posture than merely making and doing. I worry that the latter are over-large categories, lost in a sea of extant practices, justified by norms worked out by someone other than you.

In China this summer, I had the great pleasure of teaching 32 students from all over: China, Macau, Wales, Colombia, Puerto Rico, and the United States. We came together for three weeks to make opera, collaboratively, in small groups. A typical assignment was to create a prelude (or interlude, or instrumental piece) that was inspired by nature. In one class period, we might listen to Joan Tower's Sequoia and John Adams's Canticles of the Holy Wind. His "Cadenza of the Mockingbird" is paired with another recording-the actual northern mockingbird (music or birdsong?) as documented by the Cornell Lab of Ornithology. "How is nature experienced in Chinese art?" I ask (notice I say experienced, not understood). "How is Western art experienced?" Following a spontaneous line of thought, we consider Messiaen's Catalogue D'Oiseaux. The word catalogue becomes sticky with Enlightenment thought and the science of art. My Chinese students push back, talking freely about feelings and evocations; they don't use words like catalogue or encyclopedia in relation to art. Finally, we look at shan shui paintings (mountain-water art), even glorious tattoos of shan shui inked skin. Together we notice and discuss the place of people in shan shui art-so tiny, so lost in thought and feeling. The class ends with a tableau vivant-a musical sound-sculpture of mountain-water art, performed antiphonally, using any sound available.

Can open-ended teaching ensure that criticality emerges? Can creative, student-centered teaching ensure that students will arrive at the proper rendering of a socially just and anti-racist disposition? Of course it cannot. But in contrast, even a teacher-directed attack on any problem of significance cannot guarantee the results a teacher holds for her students-this is what Dewey means when he Music Education 16 (1): 163-72. doi:10.22176/act16.1.168 
says that learning (as opposed to training) is arrived at indirectly. ${ }^{6}$ Take the example above wherein students were challenged to think deeply about the intersections of nature, art, society, and what it means to be human at this moment in time. This assignment led one group to create an opera around the very recognizable theme of cell-phone preoccupation/addiction. They explored the idea that "nature" today is experienced virtually. Through a simple device like a cellular phone, have we lost a primary connection to life and living? Or, is technology the new natural world? Their one-act opera (five songs, one or two pivots) becomes about naming and repairing-rejecting lives of isolation and acting differently in the world. I think their invention signals that some kind of social justice education took place-though the word "social justice" is less important to me than the surplus of meanings and actions that are attached to it. I don't teach social justice as some kind of Work or Law, and I refuse to be the social justice Master. But what I can do is facilitate encounters where students name (read) and repair (write) through the act of collaboration and creation.

"Naming" is why I attack so vigorously the notion of Master, with his gendered capital M. Before we can repair the abuses of power that extinguish souls like Johanna from chapter one (recall, the music performance major who was told that she was very unmusical by her teachers) you must begin to name what you see, what you believe is true. This is not an exercise in classification or clarity, per se-"I now explain the conditions that define the Master." Rather, it is about exploring what the experience of being "Mastered" has meant for you, or for anyone who has majored in music or dance, and how we might imagine an arts education that refuses its inherent violence. We must not pass our abuses on! We must not become the new Master! It is very interesting to me that people want to rescue the Master. So I ask and I will keep asking, couldn't we just let go of him altogether? Couldn't we be different kinds of experts, different kinds of teachers and facilitators? I wonder why (and this breaks my heart) I have had so many conversations about Johanna? Collective guilt? Secret shame? Why do people still say to me, with a straight face: Maybe Johanna was in the wrong school? Maybe Johanna's teachers did her a favor? If I could have one wish, I would like to meet Johanna one day and thank her for her strength and passion.

I confess I was nervous about how to respond to the reviews in this special edition, in part because they are so spectacularly diverse. I was also uninterested in a defensive posture, as each writer felt so convincing and passionate. The issue's editor, Vincent Bates (for whom I also owe a great deal of thanks for his 
support and commitment; likewise, a sincere note of appreciation to Deborah Bradley who is editor-in-chief for MayDay Group Publications) made a simple request: how would you like readers to approach this issue? Hopefully, it results in more questions than answers (a classic trope, but true). Nonetheless, my questions cannot be yours. You must make your own. But I will share with you some of what I have learned.

From David Elliott and Marissa Silverman, I wonder how large or how comprehensive a philosophy of music education needs to be? My book is intentionally small, with just one or two themes. The problem of writing a great Work is that it must be defended at all costs, or else it fragments and becomes a text, dissolving like sugar in a hot cup of tea. Wayne Bowman makes me wonder if I have created art, and not philosophy (a compliment, if true). His attraction to hard analysis is admirable, but I think we both agree that we needn't share the same approach or way of thinking. I have partially addressed some of Deborah Bradley's concerns. Her contribution makes me convinced that I must write more about how a music teacher facilitates open-ended learning, and how justice and democracy can emerge and be interrogated in an open "seminar" or "laboratory" setting. When the stakes are high, as they are when we use a term like social justice, maybe closed concepts are more effective at directing change than processes that are open.

Susan Koff makes me realize how much the disciplines of dance and music education overlap, but how little we collaborate in reimaging practices. David Hansen asks us to consider the renewing affects of an open tradition, wherein traditional teaching has an obligation to reinvent and cherish, while attending to the dignity of others. Cathy Benedict makes me wonder if constructivism is my own closed form. Has my tradition become so comfortable that I cannot see the fences that surround me? Daniel Shevock has inspired me to think about notions of reclaiming and repurposing, with its ecological underpinnings. Concerning Becky Marsh, Adrienne Rodriguez, Amy Lewis, Latasha Thomas, and Juliet Hess: what do we do when writers are seen as contradicting themselves? I think of Jerome Bruner who spent a very long life in public, all the while correcting his thinking. How do we move in and out of ideas, and still profess leadership? How do we write with conviction and explore at the same time?

In closing, and with thanks all around, I cherish one thought. No reviewer has argued against openness. No one is suggesting that life and living are too open. All we need to do is look around. We hear talk of building walls. There is a 
great resurgence in nationalism. Democracy is under attack. Schools and universities are bound tighter and tighter by regulation and compliance. Outcomes reign. Process withers. This book is a counter-narrative, a plea, a longing...

Paul Woodford once called me a romantic. Maybe I am. But can I share a secret? After I finish a piece that I have written, and before I send it away, I will play a special song. It's from Sondheim's Sunday in Park with George. I like the lines that go:

Stop worrying if your vision is new

Let others make that decision

They usually do

You keep moving on...

I leave this book in your hands. And I will keep moving on.

$\approx$ Randall

August 7, 2017

Xiamen City, China

\section{About the Author}

Randall Everett Allsup is Associate Professor of Music and Music Education at Teachers College Columbia University. He identifies as a music teacher educator with a commitment to the arts and humanities, diversity, and social justice. Recently, he has been working closely with music educators across China and Japan. More information can be found at www.reallsup.com

\section{Notes}

${ }^{1}$ Randall Everett Allsup, Remixing the Classroom: Toward an Open Philosophy of Music Education (Bloomington: Indiana University Press, 2016).

${ }^{2}$ Edward Said, Culture and Imperialism (New York: Knopf, 1994).

3 Randall Everett Allsup, "The Eclipse of a Higher Education or Problems Preparing Artists in a Mercantile World," Music Education Research 17, no. 3 (2015): 251-61.

4 Barthes Roland, "From Work to Text" in Image Music Text, trans. Stephen Heath (New York: Hill and Wang, 1977), 157.

5 ibid.

Allsup, Randall Everett. 2017. Re: Re/mixing the Remix. Action, Criticism, and Theory for Music Education 16 (1): 163-72. doi:10.22176/act16.1.166 
${ }^{6}$ See John Dewey, "How We Think," in The Middle Works of John Dewey, 18991924, vol. 6: 1910-1911, ed. by Larry A. Hickman (Carbondale and Edwardsville, Illinois: Southern Illinois University Press, 2003), 224. 